\title{
Montaigne, Lear, and the Question of Afterlife
}

\section{George Hoffmann}

\section{(2) OpenEdition \\ 12 Journals}

\section{Édition électronique}

URL : http://journals.openedition.org/shakespeare/168

DOI : $10.4000 /$ shakespeare. 168

ISSN : 2271-6424

Éditeur

Société Française Shakespeare

\section{Édition imprimée}

Date de publication : 1 novembre 2004

Pagination : 155-173

ISBN : 2-9521475-0-7

\section{Référence électronique}

George Hoffmann, "Montaigne, Lear, and the Question of Afterlife ", Actes des congrès de la Société française Shakespeare [En ligne], 21 | 2004, mis en ligne le 31 janvier 2007, consulté le 19 avril 2019. URL: http://journals.openedition.org/shakespeare/168 ; DOI : 10.4000/shakespeare. 168 


\section{Shakespeare et Montaigne vers un nouvel humanisme}

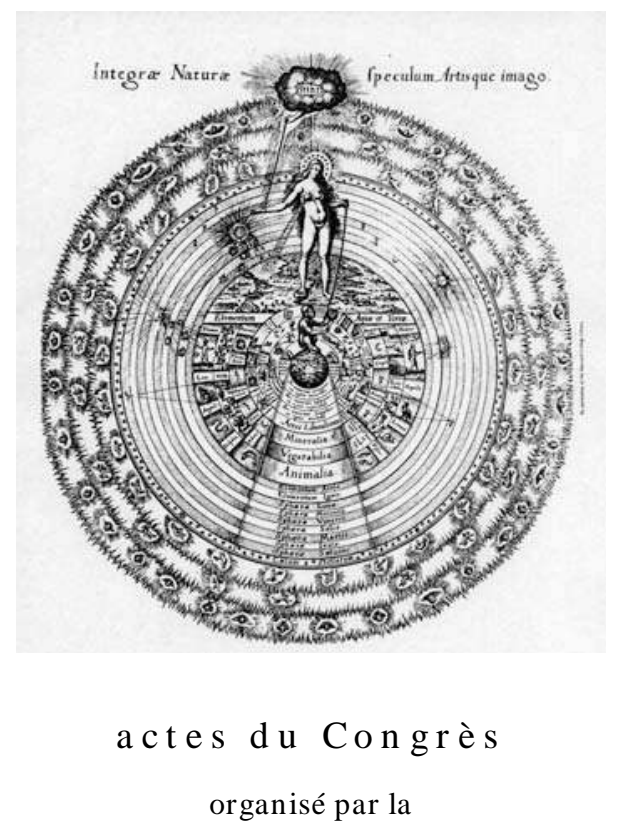

SOCIÉTÉ FR ANÇAISE SH AKESPEARE en collaboration avec la

S OC I É T É I N T E R N A T I O N A L E DES AM I D E M O N A I G N les 13,14 et 15 mars 2003

$$
\begin{gathered}
\text { textes réunis par } \\
\text { Pierre KAPITANIAK } \\
\text { sous la direction de } \\
\text { Jean-Marie MAGUIN }
\end{gathered}
$$




\section{COMITÉ SCIENTIFIQUE :}

Margaret Jones-Davis

Gisèle Venet

Jean-Marie Maguin

Yves Peyré

François Laroque

Pierre Kapitaniak

\section{COUVERTURE :}

Robert Fludd

Utriusque Cosmi Historia (1617-19)

planche 17

conception graphique et logo

Pierre Kapitaniak

\section{(C) 2003 Société Française Shakespeare}

Institut du Monde Anglophone

Université de Paris III - Sorbonne Nouvelle

http:// univ-montp3.fr/SFS/

5 rue de l'École de Médecine

75006 Paris

Diffusion :

AVL DIFFUSION

Parc Euromédecine

34198 MONTPELLIER CEDEX 5

ISBN 2-9521475-0-7

Tous droits de traduction, de reproduction et d'adaptation réservés pour tous les pays 


\title{
Montaigne, Lear, AND THE QUESTION OF AFTERLIFE
}

\author{
George HOFFMANN
}

\begin{abstract}
Holding his dead daughter, old Lear suddenly believes he sees something given to none of this life to behold: "Look, her lips, / Look there, look there," he vainly bids the other players, as Cordelia's soul, heaven bound, issues from her limp body. In making these a dying madman's words, however, Shakespeare invites his audience to consider rather the fact that we see nothing, and thus to reflect upon the gaping void that seems to lie between Christian promises of salvation and the play's depiction of a bleak, inhospitable universe. Thirty years earlier, Montaigne staged this same scene, to much the same effect, in his essay "Of exercise," casting himself not only in the roles of both Lear and Cordelia, but also in that of the duly skeptical spectator. This paper seeks to situate these two ambiguous stagings of the Christian "death" in a wider social context of popular anxiety about salvation and native skepticism over the immortality of the soul. It argues that Montaigne purposely evokes a tradition of heterodoxical responses to the problem of death beginning with the second chapter of the Wisdom of Solomon and stretching to Anabaptism. Instead of a Christian afterlife, Montaigne intimates that his spirit will live on not in his resurrected body but in a mummy, "I expose myself entire: my portrait is a cadaver on which the veins, the muscles, and the tendons appear at a glance (Frame, 274), the mummy, then, of his book, tightly bound in dried pigskin.
\end{abstract}

Montaigne, Lear et le problème de la vie éternelle Tenant le corps de sa fille morte, le vieux Lear croit tout d'un coup s'apercevoir de ce qu'aucun de ce monde ne peut contempler : "Regarde, ses lèvres, / Regarde là regarde là ", prie-t-il en vain les autres interprètes pendant que l'âme de Cordelia abandonne son corps inanimé pour le ciel. Mais en rapportant ceci à travers la parole d'un homme déséquilibré et mourrant lui-même, Shakespeare invite son public à réfléchir plutôt sur le fait que nous ne voyons rien, et sur l'abîme qui sépare les promesses du salut chrétien d'une part, et de l'autre, l'image d'un univers inhospitalier dépeint tout au long de la pièce. Trois décennies auparavant, Montaigne mettait ce même dispositif en scène dans son essai "De l'exercitation " jouant non seulement les rôles de Lear et de Cordelia, mais aussi celui du spectateur dûment sceptique. Cette communication cherche à placer ces deux mises en scène ambiguës de la "belle mort" chrétienne dans un contexte plus large de l'inquiétude populaire sur le salut et du scepticisme autochtone sur l'immortalité de l'âme. Nous proposons que Montaigne évoque délibérément une tradition de réponses hétérodoxes au problème de la mort, allant du deuxième chapitre de la Sagesse de Salomon jusqu'à l'anabaptisme contemporain. Au lieu de l'au-delà chrétien, Montaigne suggère que son esprit perdurera non pas dans son corps ressuscité mais dans la momie de son livre, relié en vélin et où " Je m'estalle entier : c'est un Skeletos où, d'une veuë, les veines, les muscles, les tendons paroissent » (II, 6, 379c).

As virtuous men pass mildly away, And whisper to their souls to go, Whilst some of their sad friends do say, "The breath goes now," and some say "No"..

John Donne

$\mathrm{H}$ olding his dead daughter at the end of King Lear, the selfdeposed king and broken-hearted father suddenly believes he sees something given to none of this life to behold; "Look, her lips, / Look there, look there," he vainly bids the other players. On the strength of the earlier lines, "Lend me a looking-glass / If that her breath will mist or stain the stone" (v.iii.235-6), most critics 
understand Lear's attention to her lips as the vain hope to find her breathing resuscitated. Yet, moments later, Edgar will bid the unconscious Lear, "Look up, my lord," to which Kent responds "Vex not his ghost, O let him pass" (287-8); the second exchange suggests that what Lear desired to see was rather Cordelia's soul issuing from her limp body, heaven bound. In expressing this hope through a dying madman's words, however, Shakespeare invites his audience to consider rather the fact that we see nothing, and thus to reflect upon the void that separates Christian promises of salvation from the play's depiction of a bleak, inhospitable universe. ${ }^{241}$ Thirty years earlier, Montaigne staged this same scene, to much the same effect, in his essay "Of exercise," casting himself not only in the roles of both Lear and Cordelia, but also in that of the duly skeptical spectator.

The essayist suffered hemorrhaging and a severe concussion after being knocked from his horse in the late $1560 \mathrm{~s}$. Wavering on the brink of death, he calls his reader's attention to his lips, as Lear would do to Cordelia's, Il me sembloit que ma vie ne me tenoit plus qu'au bout des lèvres: je fermois les yeux pour ayder, ce me sembloit, à la pousser hors, "It seemed to me that my life was hanging only by the tip of my lips; I closed my eyes in order, it seemed to me, to help push it out" (II, 6, 72; 374a; 269). ${ }^{242}$ Here, invoking the hallowed formulae of a traditional Christian death, Montaigne stages Lear's vision of the eternal soul taking leave of its mortal trappings. Or Lear's delusion, more precisely, for after attenuating this impression through the repeated "seem," he immediately judges this intimation of immortality a mere illusion. Frame translates Montaigne's "imagination" as "idea," but the rest of the sentence makes clear that this is but a figment qui ne faisoit que nager superficiellement en mon ame, aussi tendre et aussi foible que tout le reste, "that was only floating on the surface of my

\footnotetext{
${ }^{241}$ Despite the impressive erudition that Elton mobilizes to scrutinize religious attitudes in Lear, he remains curiously reticent regarding these lines, acknowledging only in a note that they might allude to the tradition of the soul passing through the mouth, and preferring the simpler reading by which the "illusion" Lear experiences is merely the one that Cordelia might still be breathing, 258, n. 210, and 334. I thank Debbie Losse and François Rigolot for allowing me to present this at the annual Renaissance Society of America's conference in 2002, as well as Philippe Desan for inviting me to present this at the University of Chicago that same year, and I am grateful to him and all those present, including Peter Dembowski, Larry Norman and Thomas Pavel, for their helpful suggestions. Finally, I thank Warren Boutcher for his kind support.

242 References are to the Tournon edition, followed by the Villey-Saulnier one, and then Donald Frame's translation.
} 
soul, as delicate and feeble as all the rest" (II, 6, 72; 374a; 269-70). The departure of his eternal soul is but an idea to which he pays lip service, seulement en la bouche, according to the popular expression of the time. ${ }^{243}$

To my knowledge, André Tournon was the first to call attention to these lines, but modern preoccupations have continued to lead most readers away from their religious implications (138-41). For example, Louis Marin quotes the sentence in a perceptive article on the essay's "unutterable cogito of death." That formula is finely put, but Montaigne's notation on the "sweet feeling" of letting go lures Marin into reflecting on the death-wish and Thanatos impulse rather than the author's pointed obliviousness to the hope of eternal life (50). Yet from the start, Montaigne has maneuvered to place these comments in a quintessentially religious perspective, launching the essay with the anecdote of Canius Julius waiting calmly at his execution to discern quelque deslogement de l'ame, "any dislodgment of the soul" (II, 6, 68; 371a; 267). That phrase, absent in Seneca's De tranquilitate animi, imparts a distinctly Christian inflection to Canius' philosophical desire to learn quis esset animarum status, "what the state of the soul really is" (XIV, 9, 271). Montaigne seems to displace the question begged by his near-fatal accident onto Seneca's Canius who promises Vos quaeritis an immortales animae sint; ego iam sciam, "You are wondering whether souls are immortal, but I shall soon know." How could Montaigne not have recalled the famous chorus, post mortem nihil est ipsaque mors nihil [...] mors individua est, noxia corpori / nec parcens animae, "There is nothing after death and death itself is nothing [...] Death is something that admits no cleavage, destructive to the body and unsparing of the soul," from Seneca's Troades (1: 156-7, lines 397, 401-2; Montaigne quotes the end of this speech, I, 3, 67; 21c; $13)$ ? Of the many who had sought to act as dispassionate observers of their own expiration, Montaigne laconically comments, ils ne sont pas revenues nous en dire les nouvelles, "they have not come back to tell us news of it." Qualifying these ancients' findings (or lack thereof) as "news" once again frames the discussion in a decidedly Christian context, namely that of the one person from past times who notably did

243 Cf. Il m interrompit pour me prier d'en user ainsi, et de monstrer par effect que les discours que nous avions tenus ensemble pendant nostre santé, nous ne les portions pas seulement en la bouche, mais engravez bien avant au cueur et en l'ame, Montaigne, "Lettre sur la mort de La Boétie," Euvres complètes, ed. Thibaudet and Rat, 1353. 
return to bring the "Good News" of everlasting life, but about whom Montaigne, seemingly deliberately, remain s silent. ${ }^{244}$

Such silence seems all the more striking in that his "they have not come back to tell us news of it" recalled a passage that served as a lightening rod in Renaissance debates over the immortality of the soul. The second chapter of the apocryphal Wisdom of Solomon, still considered canonical at the time, relates the reasoning of unbelievers:

no one has been known to return from the dead. Because we were born by mere chance, and hereafter we shall be as though we had never been; because the breath in our nostrils is smoke, and reason is a spark kindled by the beating of our hearts. When it is extinguished, the body will turn to ashes, and the spirit will dissolve like empty air [...] our life will pass away like the traces of a cloud and be scattered like mist that is chased by the rays of the sun [...] Come, therefore, let us enjoy the good things that exist (2.1-6). ${ }^{245}$

The memorable simile, "our life will pass away like the traces of a cloud," finds a faint echo in Montaigne's c'estoyent des pensemens vains, en nuё, "these were idle thoughts, in the clouds" (II, 6, 76; 376a; 271). His description of his failing faculties reverberates with the depiction of the dying soul dissolving "like empty air": ce que l'ame $y$ prestoit, c'estoyent en songe, touchée bien legierement, et comme lechée seulement et arrosée par la molle impression des sens, "what the soul contributed was in a dream, touched very lightly, and merely licked and sprinkled, as it were, by the soft impression of the senses" (II, 6, 76-7; 376a; 272). François Garasse called the book of Wisdom, after Pomponazzi, Paracelsus, and Machiavelli, la quadrature du cercle des atheistes, "the squaring of the atheist's circle" (1013); in particular, Pomponazzi's writings on the identical nature of the soul and the body recall Montaigne's marked insistence in this essay that the two go hand in hand: et l'ame et le corps enseveli et endormy, "soul and body were

\footnotetext{
244 See Legros, however, on exaggerations of Jesus's absence from the Essays.

245 Apologists made frequent reference to this passage, and often quoted or paraphrased extensively from it. For example, Extinctus cinis erit corpus nostrum, et spiritus effundetur tanquam malis aër, transibit vita nostra tanquam vestigium nubis, ex nihilo nati sumus, et post hoc erimus tanquam non fuerimus, qui fuimus afflatus est in narribus nostris, et sermo scintilla ad commovendum cor nostrum, etc. Crespet $224^{\mathrm{v}}$; Les meschans ont dit en eux-mesmes, Le temps de nostre vie est bref, \& avec ennuy, \& n'est aucun qui soit conu estre retourné des morts, car nous sommes nais de rien, \& apres ce nous serons come si nous n'eussions point esté. Car nostre corps sera cendre esteinte, \& l'esprit sera espars comme le mol air, \& nostre nom sera oublié avec le temps, La Noue 21; see, also, La Primaudaye 289r, 1615 ed.: 336-7; and Du Pont [Le Heurte] 7r.
} 
buried in sleep," and Quand aux functions de l'ame, elles naissoient avec mesme progrez que celles du corps, "As for the functions of the soul, they were reviving with the same progress as those of the body" (II, 6, 72; 374a; 269-70). Indeed, his memory of the impact only returns once his body can sense pain again. La Primaudaye rehearsed a common conception of the pair's connection, Le corps et l'ame sont de nature tellement liez et conjoincts encemble, quil n'y a que la mort ravissant tout [...] qui les puisse separer, "the body and soul are so linked and joined by nature that only death, which ravishes everything [...] can divide them" (5). ${ }^{246}$ Yet, it is precisely in the proximity of death, when the two should loosen their bond, that Montaigne insists his body and soul's fates remain more entwined than ever.

Montaigne's essay might have sounded a number of other distinctly heterodoxical notes to sixteenth-century ears. First would come the blatant contradiction with his own promotion of the Spanish theologian, Raymond Sebon. Sebon had founded his argument against the grand nombre de personnes qui jugent leur ame n'estre rien sans le corps, et qui mesurent son vivre et sa duree à la vie, et au durer de leurs membres, "great many people who judge their soul to be nothing without the body, and who measure its longevity by their lives and the longevity of their limbs," precisely upon the prolongation of mental operations, particularly the acts of willing and desiring, as the body declined. In fact, these faculties, in Montaigne's translation of Sebon, se fortifient et augmentent, "fortify and augment themselves," when facing imminent death (Euvres complètes, ed. Armaingaud 10: 49, 512). His essay, on the contrary, denies that à un si grand estonnement de membres et si grande défaillance des sens, l'ame peut maintenir aucune force au dedans pour se reconnoistre, "with... so great a failing of the senses, the soul could maintain any force within by which to be conscious of itself" (II, 6, 74; 375a; 270).

Against the background of religious debate in his time, Montaigne's argument that the dying avoient et l'ame et le corps enseveli et endormi, "their soul and body were buried in sleep" (II, 6, $73 ; 374 \mathrm{a} ; 270$ ) would have called to mind the controversial belief, attributed variously to Anabaptists, Catabaptists, and Psychopannychists, that the soul fell asleep at death. The Council of

246 Or: Nam nec anima per se est homo, nec corpus est homo, sed una ambo honmo sunt (Postel 9), quoted by Febvre, 209, trans. 197-8. 
Florence in 1439 and the Fifth Lateran Council in 1513 (session 8) both explicitly condemned this doctrine, maintaining that the soul remained awake and conscious through and after death. Calvin, notably, inaugurated his theological career in attacking the heresy of psychosomnolence; and he would go on to affirm that at the moment of death souls sentent et cognoissent, "feel and know" (3: 377-451, trans. 125) whereas Montaigne argues at length exactly the opposite, la foiblesse de mon discours me gardoit d'en rien juger, et celle du corps d'en rien sentir, "the weakness of my understanding kept me from having any judgment of it, and that of my body of having any feeling of it" (II, 6, 77; 377a; 272). ${ }^{247}$ The essayist repeatedly draws an analogy between death and a sort of cerebral sommeil: Il semble que cette consideration deut partir d'une ame esveillée, si est-ce que je n'y estois aucunement, "It would seem that this consideration must have proceeded from a wide-awake soul; yet the fact is that I was not there at all" $(77 ; 377 \mathrm{a} ; 271)$, les douleurs que le pied ou la main sentent pendant que nous dormons, ne sont pas à nous, "the pains which the foot or the hand feel while we are asleep are not ours" (76; 376a; 271); and he compares his approach to death, with the sibilant assonances of soft snoring, to those qui se laissent glisser au sommeil, "who let themselves slide into sleep" $(73 ; 374 a ; 270)$. Elsewhere, he speaks of his fainting as containing an element of pleasure, comme d'un passage au sommeil et au repos, "as when we pass into sleep and rest" (II, 13, 447; 610a; 462) and, memorably, of death, je me plonge la teste baissée, stupidement, dans la mort, sans la considerer et recognoistre, comme dans une profondeur muette et obscure, qui m'englouitit d'un saut et accable en un instant d'un puissant sommeil, plein d'insipidité et dindolence, "I plunge head down, stupidly, into death, without looking at it and recognizing it, as into a silent and dark abyss which swallows me up at one leap and overwhelms me in an instant with a heavy sleep free from feeling and pain" (III, 9, 287; 971b; 742).

Comparing death to sleep counted as a classical commonplace, but Montaigne foregoes the opportunity to argue for the survival of the soul by analogy to the sleeper's mind which dreams even as the body rests. Instead, in sleep, nous perdons la connoissance de la lumiere et de nous! [...] la faculté du som meil qui nous prive de toute action et de

${ }^{247}$ Farley translates "are alive and conscious"; I have adopted a more literal translation to maintain the similarity between the French texts. 
tout sentiment, "we lose consciousness of the light and of ourselves [...] deprives us of all action and all feeling": this is the l'eternel estat, "eternal state" that awaits humankind (II, 6, 69; 372a; 268). Montaigne seems to return the common Christian metaphor of death as a spiritual "rest" to its literal origin, the loss of consciousness that occurs in sleep. Calvin concluded that it is "offensive to human intelligence and the Christian faith to hold that souls are put to sleep at the very time they are closest to God in order to be more perfectly conscious of His goodness, all Christendom has viewed such a fantasy with horror [...] 'sleep' does not belong to the soul but ought to be attributed entirely to the body" $(141,144)$. In fact, death was precisely the time at which the soul should be most alert, as reminded Jacques Davy du Perron's Funeral Oration for Ronsard, in which the poet excitoit [son âme] courageusement à se préparer à ce bienheureux department [...demandant] si elle vouloit dormir alors qu'il estoit temps de songer à desloger, et si elle vouloit demeurer engourdie en cette masse corporelle, "courageously exhorted [his soul] to prepare itself for this blessed separation [...asking] if it wanted to sleep when it was time to think about dislodging, and if it wanted to remain asleep in this bodily mass" (94, ed. Simonin 123).

Of course, Augustine speaks of "total death" when the soul dies as well as the body (De civitate Dei, 13: 2, 12; 20: 26; 22: 30; cf. Febvre's (tendentious) reading of this idea, 180-4), but he intends this on a figurative level and in an intention that hardly places Montaigne in a more flattering light: the soul "dies" when it is forsaken by God, signaling its future damnation: Irenaeus and Arnobius similarly claimed a damned man's soul "died" through perdition. In Montaigne's time, Pierre Crespet, following Lactantius (Divina Institutiones, 7: 5, 8-13; PL, 6: 749, 761-79), discussed another sense in which the soul could be said to die: elle ne perd pas le sentiment, "it does not loose feeling," however, since l'ame pendant qu'elle est detenuë par les liens corporels, qui sont les passions corruptibles, elle cede aux douleurs mortelles, mais après qu'elle sera separée du corps qui va à sa corruption, elle est portée au ciel, où jamais elle n'envieillit, "the soul, while still held by bodily bonds, which are the corruptible passions, yields to mortal agony, but after it has left the body which passes into decomposition, it is lifted to heaven, where it never grows old" $\left(216^{\mathrm{v}}\right.$, $\left.224^{\mathrm{r}}\right)$. So, the soul feels the pain of death, is thrown into a state of 
shock, and yet is not destroyed by it; once again, Montaigne specifically resists this solution insofar as his main argument attempts to show that the soul does not feel any pain in dying.

In sum, Montaigne's essay begins to read as a gloss on two lines from Lucretius which he quotes in the Apologie, Corpoream naturam animi esse necesse est, / Corporeis quoiniam telis ictuque laborat, "The soul must be of a corporeal nature for it is affected by the opposition and shocks of bodily objects" (De rerum natura 3.176 ; II, 12, $349 ; 550 \mathrm{~b} ; 412)$. He seems to have realized the implications of this as early as his 1564 reading of De rerum natura, when he writes on one of the flyleaves animus et anima moralis sic.., "The animus and the anima are mortal. Thus...", letting the consequence trail off in an unfinished note, but not necessarily uncompleted thought (Screech 123). Certainly, Lucretius had taught him nothing if not that the body and soul are inseparable, and he notes in his reading the extreme conjunction of the two, inseparablement joints, and again, in Latin, Coniunctissima sunt corpus et anima ergo eiusdem natura, "the body and soul are completely joined and thus of the same nature" $(302,311$, 125); the idea reappears in the Essais as l'estroicte cousture de l'esprit et $d u$ corps, "the narrow seam between the soul and the body" (I, 21, 191; 104a; 74).

In 1584, Antoine de Laval still shuddered with horror at the memory of hearing an unnamed free thinker in the company of plusieurs de nos jeunes Princes soustenir que l'ame et le sang estoit la mesme chose, que l'estre et duree de l'un perissoit quant à l'autre, et tous deux ensemble, "several of our young princes maintain that he soul and blood were the same, and the existence and longevity of one expired with the other, and both together." Laval claims to have piped up that one's eye in the dark nonetheless retains the faculty of sight; Tout à coup s'en esleve un autre plus cresté, qui croyoit avoir meilleur droict en sa Question. Si l'ame subsistoit sans le corps, elle agiroit sans ses organes. Or n'agit elle jamais sans eux, voire mesme en ce qui est de sa principalle fonction qui est d'entendre: car quand elle entend, (Arist. lib.3.de anima.) elle se sert de la phantasie, la phantasie de la forme du phantosme ou figure du corps imaginé, donc elle ne peut estre sans corps, "Suddenly there arose one more bold, who thought to have the better in the question. If the soul lived on after the body, it would have to act without its organs. Now, it never acts 
apart from them, even in its principal function which is to comprehend: for when it comprehends (Aristotle, De anima, III) it uses the faculty of phantasia, the image of the form of the outline or figure of the imagined body, thus it cannot act without [the] body" ( $388^{\mathrm{r}}$; cf. Foix's arguments against this same position, 373-4). Nor is Laval's claim uncorroborated: in 1571, Constatino Tessera was accused in Venice of claiming that l'anima nostra non e altro ch il sangue nostro, "our soul is nothing other than our blood" (Davidson 65). Interestingly, in the margin of his copy of the 1595 Essais, beside Montaigne's Une ame si rare et examplaire ne coute elle non plus à tuer qu'une ame populaire et inutile? "Does a soul so rare and exemplary cost no more to kill than a plebian and useless one?" this same Laval marked tuer une ame est une estrange façon de parler, "killing a soul is a strange way to speak" (II, 13, 440; 606c; 458; 1595 ed.: 400; see Simonin, "Antoine de Laval" and Hoffmann, "Croiser le fer"). Elsewhere, he would not mince words, and when Montaigne observed that no Christian was unbiased enough to stand as a fit judge of religious quarrels of his day, Laval noted acidly, Cela ne se dict que par les Athées, "only atheists say this sort of thing" (II, 12, 432; 600a; 454; 1595 ed.: 397).

Montaigne would seem to tempt censorious readers like Laval by his description of the blow that struck him unconscious as le foudroier, "hit us like a thunderbolt" (II, 6, 71; 373a; 269), for Christian apologists typically threatened that atheists who refused to believe in immortality would be struck down by lightning. ${ }^{248}$ Even Montaigne's only reference to the autre monde proves highly ambiguous, il me sembla que c'estoit un esclair qui me frapoit l'ame de secousse et que je revenoy de l'autre monde, "It seemed to me that a flash of lightning was striking my soul with a violent shock, and that I was coming back from the other world" (II, 6, 78; 377a; 272). Despite appearances, he is not talking about the accident itself, but rather his sudden recollection of the moment of impact the next day; according to the logic of the passage, then, the "other world" from which he returns can only be the never-never land of amnesia.

Would Montaigne, then, count as an atheist? Although he underwent what he calls the approches, "approaches" of death (II, 6, $70 ; 372 \mathrm{a} ; 268)$, he did not die. The fall from his horse constitutes but

248 Willett, however, finds in this a reference to Paul's conversion in Acts. 
an analogy to, and not a direct experience of, a state that can only be approximated asymptotically $\rightarrow$ since, according to him, it entails a loss of the very consciousness by which one could apprehend it. "M'est-il permis de parler de ma mort? Que veut dire ce syntagme "ma mort'?" as Derrida has written (48), describing death in terms of a imponderable limit of human knowledge and truth. It is an old idea: "so long as we exist, death is not with us; but when death comes, then we do not exist" wrote Epicurus to Meneceus (Montaigne: Elle [la mort] ne vous concerne ny mort ny vif: vif, parce que vous estes: mort, par ce que vous n'estes plus, "It does not concern you dead or alive; alive because you are; dead because you are no more" I, 20, 176; 95c; 66); Lucretius repeated, "We shall not feel, because we shall not be." "Death is not lived through," concluded Wittgenstein in the Tractatus. Montaigne does not claim to dispel fear of the unknown by making it known, or knowable, through any familiarity he has personally attained with it; death remains not only unknown for him, it is inherently unknowable. Quoting Epicurus, he repeats approvingly, Il est impossible d'establir quelque chose de certain de limmortelle nature par la mortelle, "it is impossible to establish anything certain about immoral nature from mortal nature" (II, 12, 300; 520c; 386). In death, there are no experts, "the one experience I shall never describe," confessed Virginia Wolf. Unlike his patron saint, the archangel Michael, who was supposed to have offered succor to the soul at the instant of its departure from the body and was accompanied by the image of a balance, symbol of the Last Judgment (Delumeau, Rassurer et protéger 321-2), Montaigne adopts the emblem of the balance to signify, rather, the suspension of judgment in accord with the famous accompanying motto, Que sais-je?

The comfort Montaigne derives from his experience is minimal when compared to that sought by his Christian and classical predecessors: whatever it is, death does not hurt (much) - rather like the quip by Woody Allen, "I'm not afraid to die. I just don't want to be there when it happens." At the same time, Montaigne's insistence on the plaisir, "pleasure" (II, 6, 72; 374a; 269) of letting oneself go militates against stoic and Christian versions of a patiently suffered "heroic" death (Delumeau, Le Catholicisme 97-102, trans. 43-7). Walter Raleigh, accused in his day as an atheist, also could question the soul's immortality in attacking clerics, yet fervently affirm it in criticizing secular society, thereby illustrating a "discontent hovering 
between faith and skepticism" (Greenblatt 101-2). Today, as well, polls show that half of all those who assent to the existence of God still cannot bring themselves to believe in their own existence after death (Vergote 60-1).

In a scene remarkably similar to Montaigne's essay, Brantôme relates how a chamber maid remained transfixed at the side of the dying Marguerite de Navarre. Afterwards, she explained that

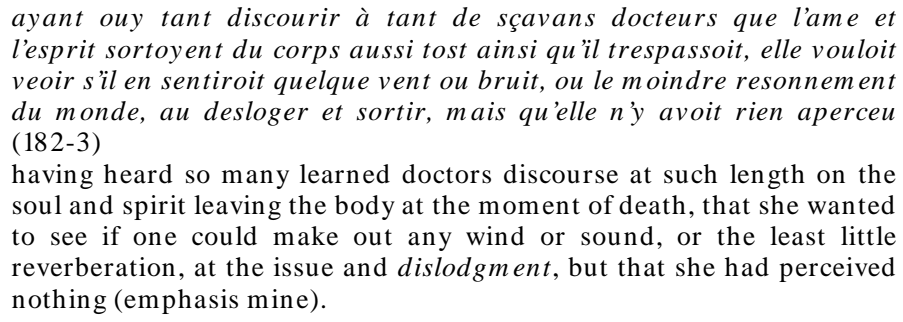
l'esprit sortoyent du corps aussi tost ainsi qu'il trespassoit, elle vouloit veoir s'il en sentiroit quelque vent ou bruit, ou le moindre resonnement $d u$ monde, au desloger et sortir, mais qu'elle n'y avoit rien aperceu (182-3)

having heard so many learned doctors discourse at such length on the soul and spirit leaving the body at the moment of death, that she wanted to see if one could make out any wind or sound, or the least little reverberation, at the issue and dislodgment, but that she had perceived nothing (emphasis mine).

Those doctors had compared the swan's dying song to the soul's departure, and so, she repeated, she vouloit veoir sortir ou sentir resonner et ouyr ceste ame ou celluy esprit, ce quill feroit à son déloger, "wanted to see leave or feel reverberate or hear that soul or that spirit, what it would do at its dislodgement." The disappointed girl confessed that she now did not know what to think of the eternity of the soul, but, she prudently hastened to reassure the gathered company, elle vouloit croire en ce que son Dieu et son Eglise commandoient, sans entrer plus avant en autre curiosité, "she wanted to believe in what her God and her Church commanded, without pushing the limits of curiosity any farther."

Brantôme's indirect swipe at Marguerite's piety resembles the manner in which Montaigne and Shakespeare encourage a skeptical response to resurrection without crossing the line of what their "Church commanded." Just as Montaigne has prepared the reader to examine dubiously his account through his earlier relation of Canius Julius's futile attempt to bring back "news" of his death, so, too, has Shakespeare primed his audience to scrutinize with distrust Lear's claim to see Cordelia's soul through the earlier, ludicrous scene of Gloucester's purported salvation on the cliffs of Dover. Edgar evokes a divine perspective, echoing the question of divine Providence raised by Gloucester's earlier “As flies to wonton boys are we to th' gods: / They 
kill us for their sport" (IV.i.37-8): "The crows and choughs that wing the midway air / Show scarce so gross as beetles [...] The fishermen that walk upon the beach / Appear like mice, and yon tall anchoring barque / Diminished to her cock, her cock a buoy / Almost too small for sight" (IV.v.13-14, 17-20). Gloucester jumps, thinking to kill himself and merely falls. Now reversing the optical perspective, Edgar invites his father to consider a gigantic demon who would have tormented him back on the cliff, "As I stood here below, methoughts his eyes / Were two full moons. He had a thousand noses, / Horns whelked and waved like the enraged sea. / It was some fiend. therefore, thou happy father, / Think that the clearest gods, who make them honors / Of men's impossibilities, have preserved thee" (IV.v.68-74).

Gloucester has literally become a plaything of the gods, save that "divine" intervention amounts to no more than Edgar's playacting. Gloucester is a fly to cruel boys, or, rather, to his own cruel boy, for Edgar, in refusing to reveal himself and thus toying with his father, is indeed cruel; as Auden famously remarked, "About Edgar hangs the shadow of impure motive. Those to whom evil is done do evil in turn." The imagination of a providential salvation assumes the measure of Gouchester's blindness, a man mocked from the start of the play for his superstitious credulity. God's omniscient vision is but a trick of distance. Hence a certain gratuitousness in Lear and Cordelia's deaths that Bradley pointed toward long ago (252-3). In each case-the blind Gloucester, the dying Lear, and the addled Montaigne-, we are put before characters who think that they have witnessed a redemption, and in each case we are invited to distrust the account given of salvation.

Though one would have expected the administration of last rites to have been the most pressing concern for all present at Montaigne's accident, they are conspicuously missing in his relation, although in best contrarian fashion, he claims elsewhere that he does ask for them when they are not needed, Tout au commencement de mes fiévres et des maladies qui m'atterent, entier encores et voisin de la santé, je me reconcilie à Dieu par les derniers offices Chrestiens, et $m$ 'en trouve plus libre et deschargé, "At the very beginning of my fevers and the maladies that lay me low, while still whole and in the neighborhood of health, I reconcile myself with God by the last Christian offices, and find myself thereby more free and unburdened" (III, 9, 304; 982b; 751). 
In the letter on La Boétie's death, closely related to this chapter, as François Rigolot demonstrated long ago, last rites are barely evoked; after duly making a profession of his faith, La Boétie bids the priest farewell, saving his last words for Montaigne's ears. Absent as well, despite all of La Boétie's loquaciousness, is the traditional bedside commendatio anima, "Deliver me, O Lord, from eternal death," and nowhere, despite his protestations of obedience to the Church, does one find the penitential formulae urged by devotional authorities. Far from appearing a Christian Antidote à la mort, "antidote to death" (Matthieu, 122 [3.3.1062-3]), and despite La Boétie's own political defense of the sacrament of extreme unction (Mémoire 1: 131-2), the Eucharist maintains a low profile, as Philippe Desan has pointed out.

Montaigne's family and friends saw to it that his own death did not suffer such embarrassing oversights, and they worked in concert to situate his demise, nearly a quarter century after his fall from his horse, within an explicitly orthodox framework. Marie de Gournay insisted in her preface to the posthumous 1595 edition, against Ceux qui pretendent calomnier sa religion that tout ainsi que jamais homme ne voulut plus de mal aux nulles et faulces religions que luy, de mesme il $n$ 'en fut oncques un plus ennemy de tout ce qui blessoit le respect de la vraye (33-4). More emphatic still was the Greek inscription that his wife, Françoise, prominently placed on his tomb in the Feuillants Abbey, Qui que tu sois, qui regardes ce tombeau et qui demandes mon nom, en disant: Est-il mort Montaigne? Cesse d'être surpris: la substance du corps, lillustration de la naissance [...] ce sont seulement des jouets périssables [...] moi qui ai su allier à la doctrine qui respecte le Christ le doute pyrrhonien. [...] j'ai été prendre mon rang parmi les immortels, où est ma patrie (Dosquet and Lamotte 22).

However, most ironic of all, given Montaigne's ambivalent attitude toward Christian models of a belle mort, is Estienne Pasquier's letter in which Montaigne fit dire la Messe en sa chambre; \& comme le Prestre estoit sur l'eslevation $d u$ Corpus Domini, ce pauve Gentilhomme s'eslance au moins mal qu'il peut, comme à corps perdu, sur son lict, les mains joincts: \& en ce dernier acte rendit son esprit à Dieu. Qui fut un beau miroir de linterieur de son Ame (48-9). Probably composed in the first years of the new century, revised until as late as 1615 , and not published until 1619 , this scene can only be based upon hearsay, third-hand information gleaned from Bernard 
Automne (Simonin 351), possibly through Florimond de Raymond, himself not present either, for Pierre de Brach, also absent, reported that Montaigne, astoundingly, had personne pres de luy à qui il peust desployer les dernieres conceptions de son ame (Letter to J uste Lipse 4 February 1593, reproduced in the Villey-Saulnier edition, 1203). The letter speaks more to Pasquier's own shift in religious self-presentation in light of his struggles against the Jesuits, and seems a calculated effort to impress its addressee, Claude Pellejay, founder of a chair of theology, friend of the prominent Jesuit at Henri IV's court, Pierre Coton, and a man by all accounts personally obsessed with preparing his own "Christian" death (Magnien 281). For Pasquier, this is the way Montaigne should have died. Pasquier's suspect letter nonetheless inspired a painting executed in 1853 by Joseph Robert-Fleury (17971890) that still hangs in the Musée du Périgord in Périgueux, Les derniers Moments de Montaigne, in which the dying writer struggles in his night robe to lift himself off the bed toward the chaplain's Eucharist at the moment of the Elevation. This picture figures vividly in the mind of the Bishop of Périgueux, come to Montaigne's chateau in 1875 to mark a thaw in the dioceses' relations with its most celebrated writer, au moment de l'élévation du 'corpus Domini,'il s'élança sur son lit les mains jointes, et rendit son esprit à Dieu (Saint-Martin 42).

Montaigne's essay traces a very different course, one in which what finally issues forth from his "lips" is his book's self-description in its fullest memorial purpose (Hoffmann, "Portrayal"). At the end of the essay, he gruesomely maintains the experience of death at the heart of his self-portrayal, Je m'estalle entier: c'est un Skeletos où, d'une veuë, les veines, les muscles, les tendons paroissent, "I expose myself entire: my portrait is a cadaver on which the veins, the muscles, and the tendons appear" (II, 6, 80;379c; 274). As an expérience inéprouvée, death establishes the defining limit of an autobiographical impulse that Blanchot terms a "suicide perpetual" $(110,105)$. Although Montaigne established a link between his project to "paint" himself and the selfportrait of René of Sicily he observed as it was presented to Francis II in 1559 at Bar-le-duc (II, 17, 515; 653a; 496), his image of the "skeletos," as Jean Balsamo suggests, alludes to another, far more famous work of art that he would have seen in that same town, the sepulchral sculpture of René d'Orange, executed by Ligier Richier fifteen years earlier (Fréchet 44-5; cf. Nakam 251-3). Montaigne's term, "skeletos," signifies 
neither a skeleton nor a cadaver proper, but a desiccated, mummified state that corresponds closely to Richier's figure, whose dried skin hangs in tatters revealing, as in Montaigne's written self-monument, "the veins, the muscles, and the tendons." Nearly unique in funerary art, this standing, gesturing transi suggests a disquieting allegory of resurrection, for it presents not a rebirth, but the reanimation of a body that remains very much that of a dead man. Despite Scripture's "O dry bones [...] I will lay sinews upon you, and will cause flesh to come upon you, and cover you with skin" (Ezekiel 37.4-6), Richier's skeletos points not toward life after death, but death after life, or, at best, a living death.

So, too, with Montaigne. The notable absence of his father among those concerned over his welfare back at the château, as well as the fact that, even while wounded, Montaigne is clearly acting as the châtelain responsible for giving orders, all make it highly probable that his fall took place during the Third War, sometime then between 23 August 1568 and 8 August 1570, in other words, immediately preceding the beginning of his literary career with his posthumous edition of $\mathrm{La}$ Boétie's writings in preparation for his own attempts at writing the Essais (Simonin, "Euvres complètes"). His recovery from the accident might explain why, nearly eight years after inheriting his friend's manuscripts, Montaigne suddenly decided to publish them. Henceforth, writing for Montaigne addressed itself to attaining the living death of literary posterity.

If this essay recounts losing one's consciousness, it nevertheless seems to grow more alertly conscious of itself, culminating in the final, added pages which Montaigne self-consciously discusses the propriety of his self-portrait (Regosin 160-5). On these last pages, "me" and "oneself" significantly replace Montaigne's preceding preference for referring to his "soul," suggesting a collapse of the soul into the self, or more precisely, the skeletos, and the abandonment of any ontological sense of identity in favor of the instance of self-consciousness-what Montaigne jokingly calls mon essence, "my essence" (II, 6, 80;379c; 274). Although his neighbor, François de Foix, insisted that the soul and the self were one, l'ame parle en premiere personne [...] la ou est l'ame, soit universele ou l'humaine, la mesmes est la pensee, "the soul speaks in the first person [...] where the soul is, there thought is" (346, 500 ), Montaigne has ironically separated the two from the essay's first 
page with Canius' vow to see if je pourray appercevoir quelque deslogement de l'ame et si elle aura quelque ressentiment de son yssuë, "I shall be able to perceive any dislodgement of the soul, and whether it will have any feeling of its departure" (II, 6, 68; 371a; 267; emphasis mine). Unable, finally, to expel his soul from his lips, Montaigne resigns himself to expressing this self through his mouth, as Ullrich Langer (80) perceptively points out in the essay's last line, $Q u i$ se connoistra ainsi, quill se donne hardimment à connoistre par sa bouche, "Whoever knows himself thus, let him boldly make himself known by his own mouth" (II, 6, 82; 380c; 275). Thus the insubstantial "empty air" into which the expiring breath dissipates, according to Solomon's atheists, becomes corps aërée de la voix, "this airy medium" of Montaigne's written voice (II, 6, 80;379c; 274).

Garasse recounted the most blasphemous last testament he had ever seen: le premier est, de ce vieux atheiste de Poitiers, lequel je ne nomme point par respect, qui ordonna par testament, que son corps seroit enfermé dans une peau de pourceau conroyée, et ensevely debout devant le grand autel de l'eglise, sur une pille de charbons, donnant pour raison de son dire, qu'il n'y avoit point d'autre dieu au monde que lincorruptibilité du corps, et que les charbons et la peau de pourceau bien conroyée, estoient deux suffisans moyens pour empescher la pourriture (915). Like the Poitiers atheist's corpse in tanned pigskin, Montaigne will preserve himself in the "mummy" of the book, bound in vellum hide, this corps solide qui puisse durer quelques années ou quelques jours apres moy, "solid body that may last a few years, or a few days, after me" (II, 37, 712; 783a; 595), a starkly personal eschatology in face of the living "flesh and bones" of the resurrected Christ (Luke 24.39). Richier's skeletos still holds an unrolled parchment, upon which writing-doubtlessly an epitaphonce figured, anticipating Montaigne's own writing in death, and of death. Thus do human dreams of finding existence after death live on within a fragile membrane of dried skin.

George HOFFMANN University of Michigan 


\section{WORKS CITED}

Balsamo, Jean. Personal correspondence. 6 April 2001.

Bible, The. The Oxford Study Bible: Revised English Bible with the Apocrypha. Ed. M. Jack Suggs, Katharine Doob Sakenfeld, and James R. Mueller. New York: Oxford University Press, 1992.

. Biblia sacra: iuxta Vulgatam versionem. Ed. Boniface Fischer et al. Third edition. Revised by Robert Weber. 1969. Stuttgart: Deutsche Bibelgesellschaft, 1983.

Blanchot, Maurice. L'Écriture du désastre. Paris: Gallimard, 1980.

Bradley, A. C. Shakespearean Tragedy. $2^{\text {nd }}$ ed. London: MacMillan, 1914.

Brantôme, Pierre de. Recueil des dames, poésies et tombeaux. Ed. Étienne Vaucheret. Paris: Gallimard, 1991.

Calvin, Jean. Psychopannychia or, a Refutation of the Error Entertained by Some Unskillful Persons, Who Ignorantly Imagine that in the Interval Between Death and the Judgment the Soul Sleeps. Tracts and Treatises on the Reformation of the Church. Ed. Henry Beveridge and Thomas Forsyth Torrance. 3 vols. Edinburgh \& London: Oliver \& Boyd, 1958. Trans. Benjamin Wirt Farley. Treatises Against the Anabaptists and Against the Libertines. Grand Rapids, Mich.: Baker Book House, 1982.

Crespet, Pierre. Suitte des discours catholiques, de l'origine, de l'essence, excellence, fin et im mortalité de l'Ame. Paris: Ch. Chappellain, 1604.

Davidson, Nicholas. "Atheism in Italy, 1500-1700." Atheism from the Reformation to the Enlightenment. Ed. Michael Hunter and David Wootton. Oxford: Clarendon Press, 1992.

Delumeau, Jean. Rassurer et protéger: Le sentiment de sécurité dans l'occident d'autrefois. Paris: Fayard, 1989.

. Le Catholicisme entre Luther et Voltaire. 1971. Third edition. Paris Presses Universitaires de France, 1985. Trans. John Bossy. Catholicism between Luther and Voltaire: A New View of the CounterReformation. London: Burns \& Oates, 1977.

Derrida, Jacques. Apories: mourir-s'attendre aux 'limites de la vérité.” Paris: Galilée, 1996.

Desan, Philippe. "Ahaner pour partir' ou les dernières paroles de La Boétie selon Montaigne." Montaigne dans tous ses états. Fasano: Schena, 2001. 13-36.

Dosquet and Lamotte, MM. Compte-rendu des Travaux de la commission des Monuments et Documents historiques et des bâtiments civils du Département de la Gironde. Paris: V. Didron, 1855.

Du Perron, Jacques Davy. Oraison funèbre sur la mort de Monsieur de Ronsard. Paris: F. Morel, 1586. Ed. Michel Simonin. Geneva: Droz, 1985.

Du P[ont], R[ené] (Matthieu Le Heurt). La Philosophie des esprits. Paris: Vve. G. de la Noue, 1602 . 
Elton, William R. King Lear and the Gods. San Marino, CA: Huntington Library, 1966.

Febvre, Lucien. Le Problème de lïncroyance au XVIe siècle. 1942. Paris: A Michel, 1968 Trans. Beatrice Gottlieb. The Problem of Unbelief in the Sixteenth Century: the Religion of Rabelais. Cambridge, Mass. Harvard University Press, 1982.

Foix, Francois de, sieur de Candalle. Le Pimandre de Mercure Trismegiste de la philosophie chrestienne. Bordeaux: S. Millanges, 1579.

Fréchet, Georges. "Bar-le-Duc, l'église Saint-Etienne." Congrès archéologique de France, Les Trois-Evêchés et l'ancien duché du Bar 149 (1991): 33 47.

Garasse, Françoise. Doctrine curieuse des beaux esprits de ce temps, ou pretendus tels. Paris, S. Chappelet, 1623.

Gournay, Marie de. "Préface à l'édition des Essais de Montaigne." Ed. François Rigolot. Montaigne Studies 1 (1989): 8-60.

Greenblatt, Stephen J. Sir Walter Raleigh: The Renaissance Man and His Roles. New Haven: Yale UP, 1973.

Hoffmann, George. "Croiser le fer avec le Géographe du Roi: L'entrevue avec Antoine de Laval aux Etats généraux de Blois en 1588." La Familia de Montaigne. Ed. John P. O'Brien and Philippe Desan. Montaigne Studies 13: 1-2 (2001): 207-22.

. "Portrayal from Life, or to Life? The Essays's Living Effigy." French Forum 25: 2 (2000): 145-63.

La Boétie, Étienne. Mémoire sur la pacification des troubles. Ed. Louis Desgraves. Euvres complètes d'Estienne de La Boétie. 2 vols. Bordeaux: William Blake, 1991

La Noue, François de. Discours politiques et militaries. Ed. F. E. Sutcliffe. Geneva: Droz, 1967.

La Primaudaye, Pierre de. Suite de l'Academie Françoise, 1580. [Geneva]: J. Chouët, 1593.

. L'Academie françoise divisée en quatre livres. Lyon, P. Frellon, 1615.

Langer, Ullrich. "Mourir et agir dans 'De l'exercitation." Bulletin de la Société des Am is de Montaigne $8^{\text {th }}$ ser., 17-18 (2000): 79-87.

Laval, Antoine de. Desseins des professions nobles et publiques. Paris: A. L'Angelier, 1605.

Legros, Alain. "Comme une autre histoire...' Montaigne et Jésus-Christ." Bibliothèque de l'Humanisme et de la Renaissance 58: 3 (1996): 577-96.

Magnien, Catherine. "Etienne Pasquier "familier" de Montaigne?" La Familia de Montaigne. Ed. John P. O'Brien and Philippe Desan. Montaigne Studies 13: 1-2 (2001): 277-313.

Marin, Louis. "Montaigne's Tomb, or Autobiographical Discourse." Oxford Literary Review 4: 3 (1981): 43-58.

Matthieu, Pierre. La Guisiade. Ed. Louis Lobbes. Geneva: Droz, 1990.

Montaigne, Michel de. Les Essais. Ed. V[erdun]-L[ouis] Saulnier and Pierre Villey. Paris: P. U. F., 1965. 
Les Essais. Ed. André Tournon. 3 vols. Paris: Imprimerie Nationale, 1998.

The Complete Works of Montaigne. Trans. Donald Frame. 1948. Stanford: Stanford University Press, 1958.

. Euvres complètes. Ed. Albert Thibaudet and Maurice Rat. Coll. "La Pléiade". Paris: Gallimard, 1962.

. Euvres complètes de Montaigne. Ed. A[rthur-Antoine] Armaingaud. 12 vols. Paris: Conard, 1924-41.

Nakam, Géralde. “Matières' d'un autoportrait." Le Dernier Montaigne. Paris: Champion, 2002. 229-57.

Pasquier, Étienne. Choix de lettres sur la littérature, la langue et la traduction. Ed. D[orothy] Thickett. Geneva: Droz, 1956.

Postel, Guillaume. De rationibus spiritus sancti. Paris: P. Gromorsius, 1543.

Regosin, Richard. "Nemo's Descent: The Rhetoric of Presence in Montaigne's Essais." French Forum 13: 2 (1988): 153-65.

Rigolot, François. "Montaigne's Purloined Letters." Montaigne: Essays in Reading. Ed. Gérard Defaux. Yale French Studies 64 (1983): 145-66.

Saint-Martin, Joseph. "Note sur Mgr. Dabert, évêque de Périgueux et deux visites qu'il fit au château de Montaigne en 1867 et 1875." Bulletin de la Société des Am is de Montaigne $4^{\text {th }}$ ser., 14 (1968): 42-3.

Screech, M[ichael] A., ed. Montaigne's Annotated Copy of Lucretius: A Transcription and Study of the Manuscript, Notes and Pen-Marks. Geneva: Droz, 1998.

Seneca, Lucius Annaeus. De tranquilitate animi / On Tranquility of Mind. Trans. and ed. John W. Basore. Vol.2 of Moral Essays. 1932. Cambridge, Mass.: Harvard UP, 1951.

- Tragedies. Trans. and ed. Frank Justus Miller. 1917. 2 vols. Cambridge, Mass.: Harvard UP, 1998.

Shakespeare, William. Euvres completes: Tragédies. Trans. and ed. Gilles Monsarrat. 2 vols. Paris: Laffont, 1995.

Simonin, Michel. "Antoine de Laval et Charles de La Mure, plumes en main" (unpublished paper).

"Bernard Automne (1564-après 1628), témoin et lecteur de Montaigne." La Familia de Montaigne. Ed. John P. O'Brien and Philippe Desan. Montaigne Studies 13: 1-2 (2001): 315-60.

. "EEuvres complètes ou plus que complètes? Montaigne éditeur de La Boétie." Montaigne in Print. Ed. Philippe Desan and Ullrich Langer. Montaigne Studies 7: 1-2 (1995): 5-34.

Tournon, André. "L'Essai, un témoignage en suspens." Carrefour Montaigne. Geneva: Slatkine, 1994. 117-45.

Vergote, Antoine. Religion, foi, incroyance: étude psychologique. Brussels: P. Mardaga, 1983.

Willett, Laura. "Montaigne, Caravaggio and the Conversion of St. Paul." Going for Baroque: Cultural Transformations 1550-1650. Ed. Francesco Guardiani. Ottawa: Legas, 1999. 137-53. 